\title{
A CONTRIBUIÇÃO DAS COMPENSAÇÕES AMBIENTAIS PARA A CONSTITUIÇÃO DE UM SISTEMA DE ESPAÇOS LIVRES PÚBLICOS NA CIDADE DE SÃO PAULO
}

\author{
THE CONTRIBUTION OF THE ENVIRONMENTAL COMPENSATIONS TO THE \\ CONSTITUTION OF A PUBLIC OPEN SPACE SYSTEM IN THE CITY OF SÃO PAULO
}

\section{Leonardo Loyolla Coelho}

Arquiteto-paisagista, mestre na área de Paisagem e Ambiente pela pós-graduação da Faculdade de Arquitetura e Urbanismo da Universidade de São Paulo e professor das disciplinas de Paisagismo e Urbanismo nas universidades Anhembi-Morumbi e São Marcos

e-mail: Iloyolla@gmail.com

\section{RESUMO}

Este artigo tem por objetivo analisar como a compensação ambiental contribui para atenuar o déficit de espaços livres públicos na cidade de São Paulo. Abordam-se os diferentes papéis desempenhados pela arborização urbana e pelos espaços livres públicos como formas de compensação aos danos causados ao meio ambiente. É também realizado o mapeamento das ações compensatórias que resultaram na produção de espaços livres públicos e uma análise dos aspectos deficitários e positivos do mecanismo, visando ao seu aperfeiçoamento.

Palavras-chave: Legislação ambiental, espaços livres urbanos, compensação ambiental.

\section{ABSTRACT}

This article focuses in the analysis of how the environmental compensation contributes to the attenuation of public open spaces deficit in the city of São Paulo. It broaches the different roles performed by the urban forestry and the public open spaces as compensations for the environmental damage. This essay also makes a mapping of the actions that resulted in the production of public open spaces and the evaluation of the positive aspects of the mechanism and the ones to be improved, aiming its betterment.

Key words: Environmental legislation, urban open spaces, environmental compensation.

\section{INTRODUÇÃO}

Embora exista uma demanda efetiva, a construção de novos espaços livres na cidade de São Paulo nunca constituiu prioridade para o poder público, tanto estadual quanto municipal. Os recursos direcionados para essa área são restritos, comparativamente a outros investimentos realizados no município'. Mesmo tendo um custo para implantação geralmente inferior ao de outros tipos de obras, a construção de praças e parques costuma ser preterida na pauta das administrações públicas, quando comparada a obras de maior visibilidade, tais como edificações ou melhoramentos viários.

O descaso do poder público também pode ser observado com relação à inadequada distribuição dos espaços livres². Muito poucas foram as iniciativas sistematizadas para implementação de áreas para lazer e convívio na cidade ${ }^{3}$. Quando existiram, as ações se voltaram, tradicionalmente, para o atendimento das áreas consolidadas historicamente como centrais e de elite, que possuem maior visibilidade e retorno político. 
Prova disso é a inexistência (até o ano de 2008) de critérios legais que orientem a distribuição de espaços livres no município. Como resultado, as áreas mais carentes são as menos beneficiadas por espaços livres públicos. Somente a partir dos anos 2000, com o surgimento de alternativas como o Programa Centros de Bairro ${ }^{4}$, o investimento em espaços livres para bairros populares torna-se uma prática recorrente, embora ainda incipiente.

Sobrecarregados pela demanda reprimida, os espaços livres existentes sofrem ainda com a falta de manutenção e a gestão inadequada - apenas mais uma evidência do desinteresse do poder público com relação a esse assunto.

Paralelamente a todos esses problemas, as possibilidades reais de atuação do poder público, no sentido de suprir a carência de espaços livres na cidade de São Paulo, tornam-se cada vez mais restritas. Tal fato se deve à redução do estoque de áreas disponíveis para esse fim. Um dos principais motivos para essa redução é a ocupação dos espaços livres públicos por outras finalidades, tais como moradia e usos institucionais pelo próprio poder público. Outro motivo é a capacidade restrita do mecanismo de parcelamento do solo, que tem gerado espaços livres fragmentados, com dimensões reduzidas e características de relevo inadequadas ao uso para lazer e convívio.

$\bigcirc$ quadro de carência de espaços livres no município começa lentamente a ser revertido de 2000 em diante, quando o Plano Diretor Estratégico do município passa a refletir o aumento da preocupação com as questões ambientais, ocorrido nos anos 80 e 90. Exemplo disso são as mobilizações da Secretaria de Verde e Meio Ambiente (SVMA) e subprefeituras para criação de parques lineares na cidade ${ }^{5}$, intensificadas a partir 2007.

As atuações isoladas do poder público e da iniciativa privada para amenizar o déficit de espaços livres públicos no município de São Paulo não têm sido bem sucedidas. A associação de ambos, embora promissora, também não tem surtido os efeitos desejados, pois se vincula, excessivamente, aos interesses da iniciativa privada.

Se a associação voluntária entre as duas esferas tem apresentado problemas, o estabelecimento de um novo vínculo legal abriu espaço para novos tipos de negociações entre o poder público e o empreendedor.

No final dos anos 90, as compensações ambientais arbóreas surgem na cidade de São Paulo como uma nova forma de interação entre o poder público e iniciativa privada. Consolidada como mecanismo legal, a compensação se tornou uma forma alternativa de captação de recursos para viabilizar novos espaços livres no município.

Ao longo de dez anos de aplicação oficial na cidade de São Paulo (1998 a 2008), as compensações ambientais foram responsáveis por uma quantidade considerável de ações relacionadas, sobretudo, à arborização urbana e à produção de espaços livres públicos.

Um cálculo simplificado permite afirmar, por exemplo, que, em um período de dois anos e meio (entre 2005 e 2007), a aplicação das compensações ambientais no município de São Paulo obteve recursos da ordem de R\$ 60 milhões (ou US\$ 34 milhões) ${ }^{6}$. 
Cabe frisar, no entanto, que essa quantia não corresponde a uma receita com a qual o poder público possa contar regularmente, mas sim a um recurso que atua de forma auxiliar (embora significativa).

\section{COMO COMPENSAR?}

A compensação ambiental consiste em uma negociação com o poder público, que atribui um valor prévio de contrapartida aos danos ambientais a serem causados por um empreendimento, seja ele privado, seja público. $\bigcirc$ princípio norteador das compensações é estabelecer contrapartidas altas o suficiente para fazer o empreendedor repensar suas ações. No caso da retirada de árvores, a medida compensatória mais intuitiva seria a troca pela mesma "moeda". Ou seja: o plantio de novas mudas em quantia superior à retirada. Existem, no entanto, diversas formas alternativas à compensação arbórea por plantio.

As compensações ambientais não podem ser encaradas como recurso orçamentário. Caso sejam utilizadas em larga escala, podem até se tornar justificativa para a degradação ambiental. Por esse motivo, a autorização para o corte de árvores só é concedida pelo poder público em situações específicas.

O mecanismo legal utilizado para a aplicação de compensações ambientais relacionadas à vegetação no município de São Paulo é o Termo de Compromisso Ambiental (TCA), que surgiu, oficialmente, a partir do ano de 19987. Na cidade de São Paulo, sob circunstâncias específicas, o plantio de vegetação pode ser trocado pela aquisição de novos terrenos para incorporação ao sistema de espaços livres municipais ${ }^{8}$ ou mesmo pela realização de obras e serviços em espaços livres públicos. Prioriza-se a aplicação das compensações no mesmo local onde ocorreu o dano ambiental, mas caso não haja espaço para tal, a compensação pode ser realizada em outro local da cidade, a ser indicado pela Secretaria do Verde e Meio Ambiente.

A idéia de trocar o plantio de árvores pela execução de obras construtivas pode parecer, a priori, um contra-senso: trocam-se árvores (e a permeabilidade dos solos a elas atrelada) por elementos construídos, que, na maioria dos casos, contribui para o aumento da degradação ambiental da cidade. Mas, por outro lado, a implantação de equipamentos em espaços livres públicos permite assegurar a função recreativa dessas áreas, contribuindo para preservá-las.

Além disso, a possibilidade de realizar obras e serviços como parte da compensação ambiental estabelece uma "moeda de troca" atraente para o setor da construção civil, que pode saldar sua dívida com o próprio serviço ao qual está habituado a trabalhar. Pode-se, desse modo, reduzir o tempo do processo compensatório. Por esses motivos, mostra-se interessante questionar a real eficiência da arborização urbana como forma única de compensação ambiental.

No contexto urbano, o papel desempenhado pela arborização só pode ser entendido adequadamente quando associado aos espaços livres que a ela dão suporte. $\bigcirc$ plantio de árvores adquire diferentes significados, caso ocorra em uma via pública, à beira de um curso d'água ou em logradouros como praças, jardins e parques. 
A compreensão do papel da arborização em espaços livres urbanos passa pela reflexão dos critérios de qualificação da paisagem, os quais, segundo Macedo", podem ser ambientais, estéticos e funcionais, sendo este último extremamente vinculado ao cotidiano das cidades.

Na maioria das vezes, esses três elementos são analisados de forma fragmentada pela população e até mesmo pelos técnicos relacionados à arborização, dando margem a diversos equívocos. Trabalhar com qualquer um desses critérios de forma isolada representa uma abordagem reducionista.

As situações mais intrigantes, no entanto, são aquelas nas quais a estética, a funcionalidade e a qualidade ambiental são ignoradas em função do mero cumprimento de formalidades burocráticas. Variados são os exemplos nos quais a arborização urbana é reduzida ao ato de preencher determinada área com a máxima quantidade de árvores possíveis, de modo a cumprir obrigações solicitadas pela legislação ambiental.

Também são diversos os exemplos de plantio realizado de forma completamente aleatória, principalmente em espaços livres públicos residuais, como terrenos de grande declividade, rotatórias e alças de acesso a vias (Figura 1). Essas ações são, paradoxalmente, incoerentes às necessidades ambientais do local onde são realizadas, pois não se baseiam na demanda efetiva existente. $O$ uso inadequado da arborização pode atuar mais como problema do que auxílio à melhoria da qualidade de vida urbana.

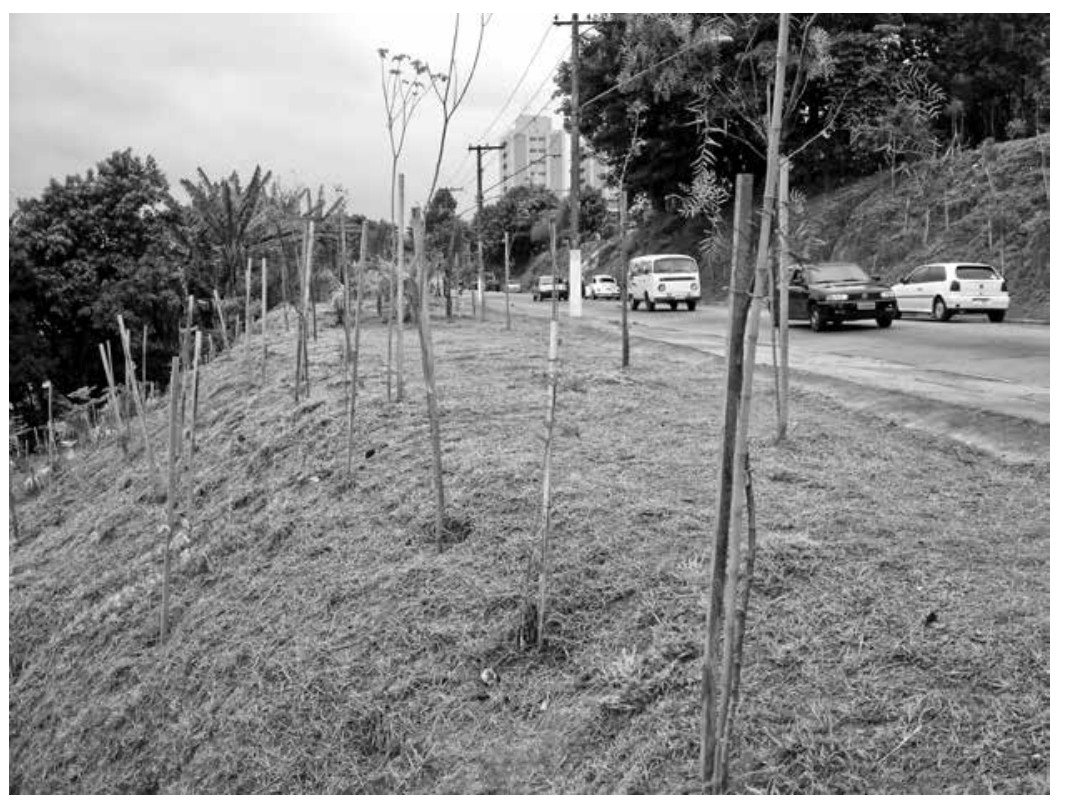

Figura 1: Plantio aleatório de mudas forma um verdadeiro "paliteiro"em talude no bairro de Tucuruvi Crédito: Foto de Maurício Alito, 2006

Naturalmente, não se sugere, aqui, que a compensação por plantio seja substituída pela realização de obras construtivas em espaços livres. O papel exercido pelas árvores, na qualificação ambiental, é fundamental. Mas a eficácia do plantio de árvores como forma de compensação tem sido revista. A idealização do plantio como ação efetiva para atenuar danos ambientais causados pela retirada de árvores foi quebrada por seu rebatimento na realidade do cotidiano. 
Empreendimentos que geram pequenas quantias compensatórias costumam representar um problema para os órgãos públicos responsáveis pelas compensações. Números maiores de árvores para compensação representam montantes financeiros mais facilmente aplicáveis, sobretudo nos casos nos quais o plantio é trocado pela execução de obras e serviços, geralmente a demandarem maiores recursos. Além disso, plantios em quantias muito pequenas, realizados de forma isolada, têm menor possibilidade de suportar atos de vandalismo e apresentam pouca significância no contexto geral da cidade.

\section{COMPENSAÇÕES AMBIENTAIS EM SÃO PAULO}

Do total de compensações realizadas no município de São Paulo entre os anos 2005 e 2007, a maioria (70\%) corresponde ao plantio de árvores ${ }^{10}$ (Tabela 1). Tal proporção, que se repete desde o início da aplicação do mecanismo compensatório em 1998, reflete a prioridade que tem sido dada pelo poder público a esse tipo de medida.

Tabela 1: Tipos de compensação ambiental realizadas no município de São Paulo entre os anos de 2005 e 2007

\begin{tabular}{l|c|c}
\hline Tipo & Qtde & $\%$ \\
\hline Plantio & 160.018 & 70 \\
\hline Conversão da medida compensatória ${ }^{*}$ & 67.871 & 30 \\
\hline Total & 227.889 & 100 \\
\hline
\end{tabular}

* Conversão da medida compensatória: formas de compensação ambiental alternativas ao plantio arbóreo, tais como obras e serviços em espaços livres públicos, aquisição de novos espaços livres, etc.

Crédito: Leonardo Loyolla

foco deste trabalho, no entanto, reside sobre as ações compensatórias que resultaram em novos espaços livres para a cidade. Analisando a localização dos mesmos (Mapa 1, Tabela 2, Figuras 2 a 11), percebe-se que eles se distribuem de forma razoavelmente homogênea pelas diferentes regiões do município. Durante a gestão Marta Suplicy - período de 2000 a 2004, no qual foram iniciados diversos projetos públicos custeados por compensações - todas as regiões da cidade (zonas leste, oeste, norte e sul) receberam, no mínimo, um espaço livre público custeado por TCAs, com exceção da área central" ${ }^{11}$.

O local de origem dessas compensações nem sempre corresponde ao entorno imediato do espaço livre custeado. Metade dos casos (praça Silvio Romero e os parques do Cordeiro, Pinheirinho D'água e Vila Prudente) foram financiados por compensações ambientais provenientes de outros bairros. Com exceção do Parque da Vila Prudente, cujas compensações vieram da própria zona leste, todos os outros casos tiveram origem na região sudoeste da cidade.

Tal fato se deve a essa região concentrar elevado número de novos empreendimentos do setor imobiliário o qual, por sua vez, estão sujeitos ao maior controle da fiscaliza- 
ção ambiental. Além disso, é o local da cidade com índice mais alto de arborização, seja ela viária, seja em outros tipos de logradouros ou intralote. A existência de uma quantia satisfatória de árvores no entorno dos empreendimentos dessa região dificulta a realização de novos plantios. Tal fato induz ao uso de medidas alternativas a este, tais como a execução de obras e serviços em espaços livres de outros locais da cidade.

Com relação à faixa de renda média das regiões que receberam os espaços livres, percebe-se equilíbrio: o Parque do Cordeiro e as praças Nandina Haddad Ambuba e Anna dos Santos Figueiredo localizam-se em áreas da cidade com maior poder aquisitivo (respectivamente Alto da Boa Vista, Morumbi e Jardim Anália Franco). O restante dos projetos - praça Silvio Romero e os parques Jacintho Alberto, da Vila Prudente, Linear do Sapé e Pinheirinho D'água - localiza-se em áreas com poder aquisitivo médio ou baixo.

Mapa 1 - Parques TCA

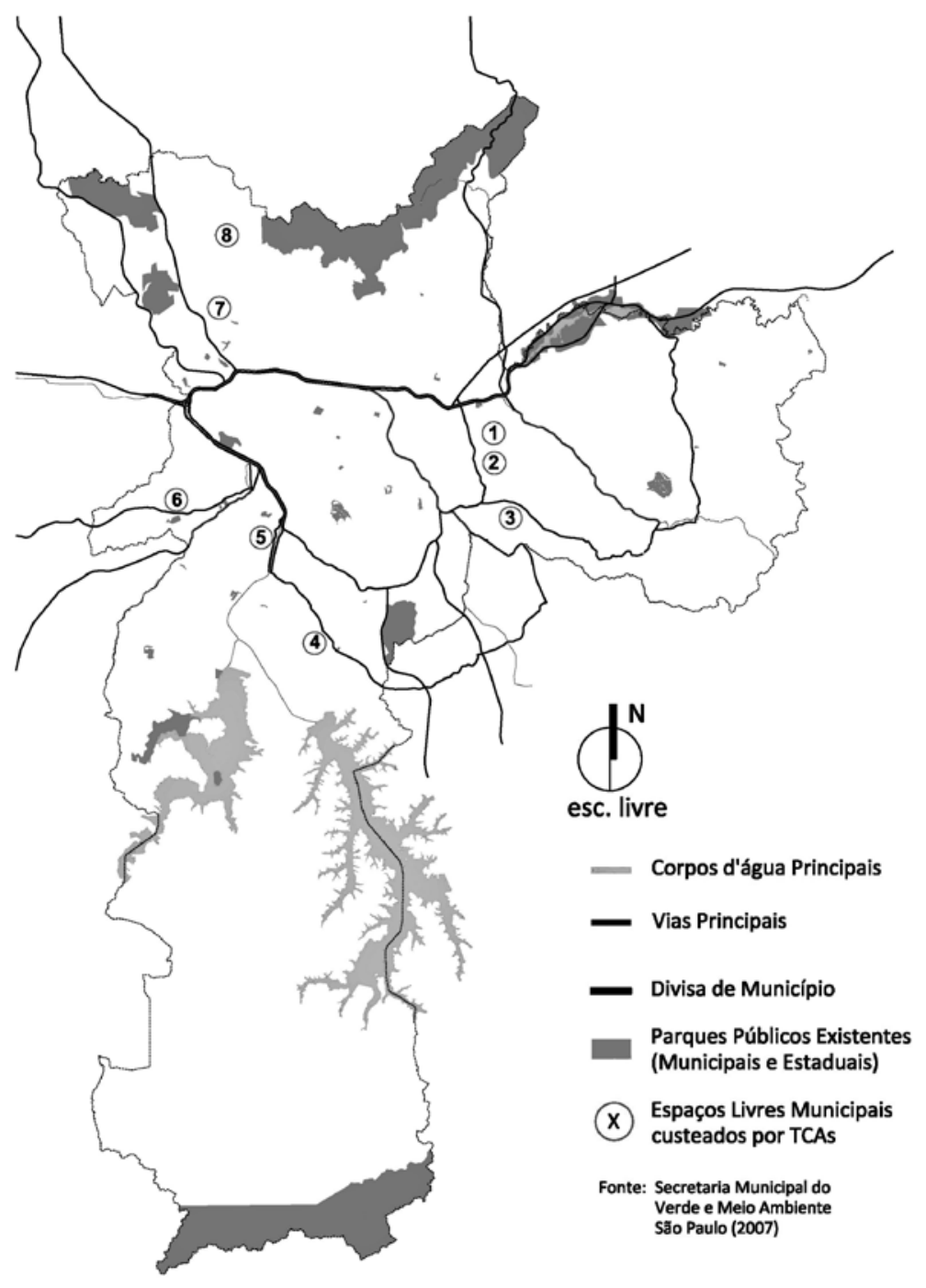




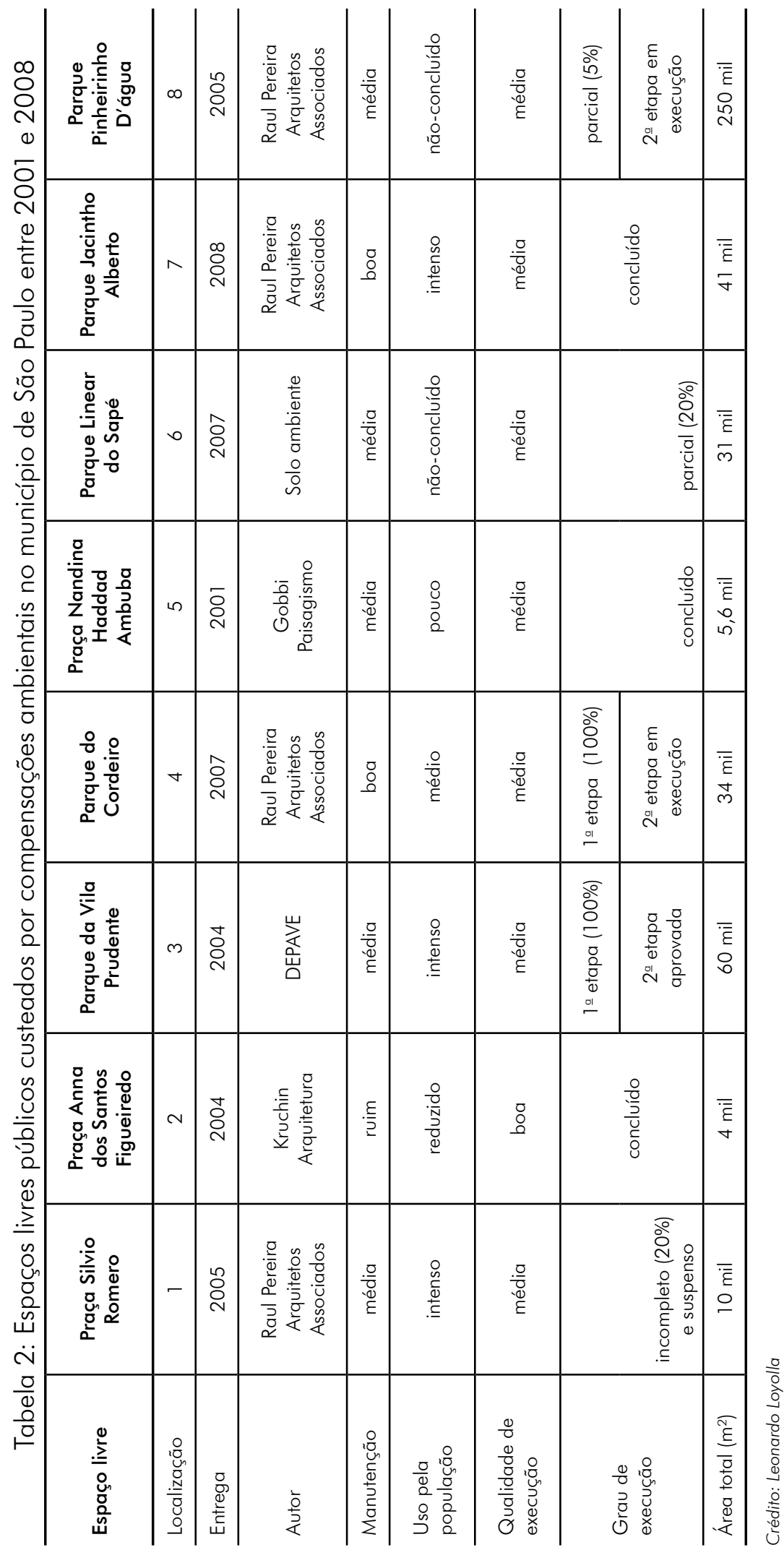




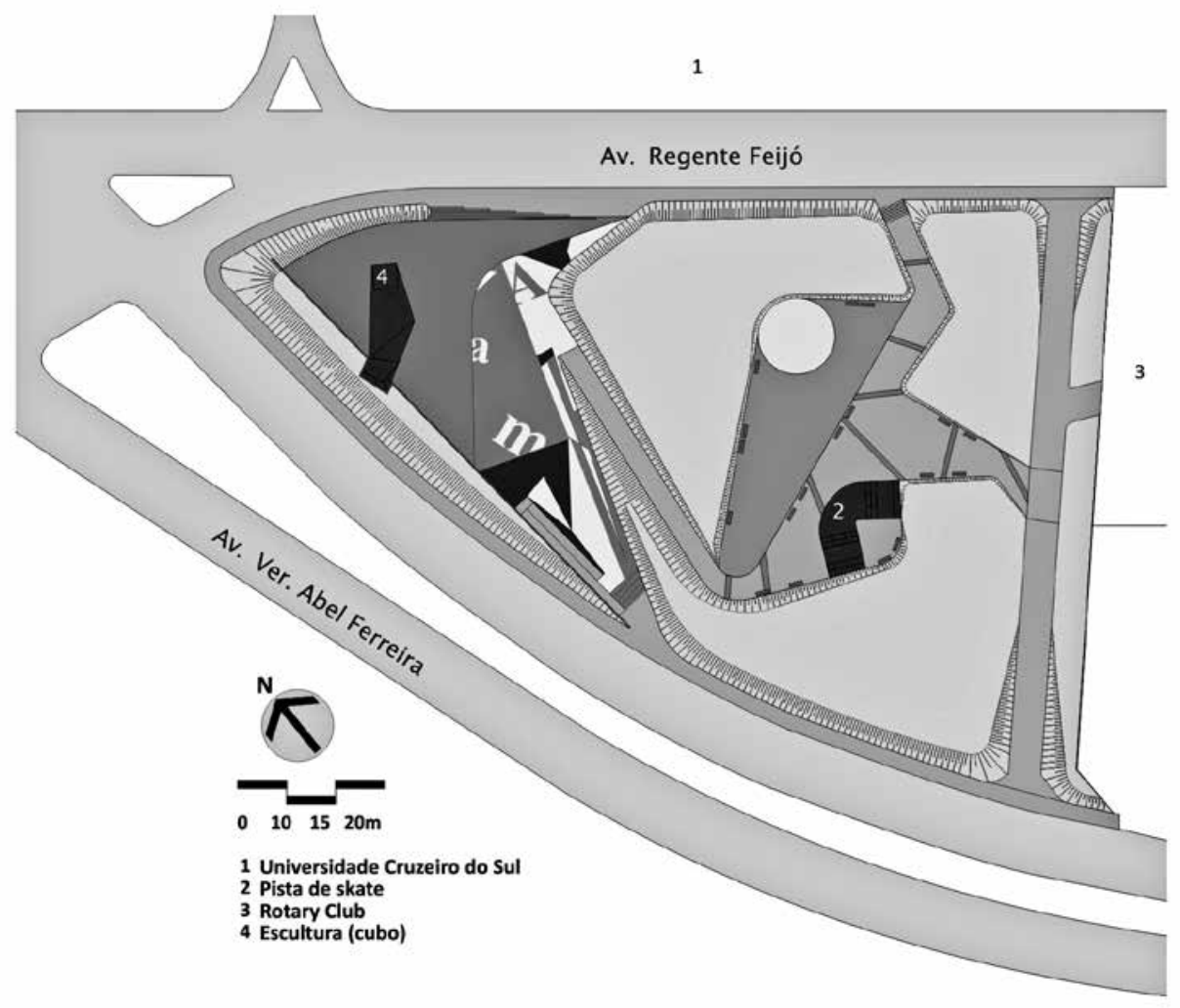

Figura 2: Praça Anna Santos Figueiredo

Crédito: Foto de Leonardo Loyolla, 2006

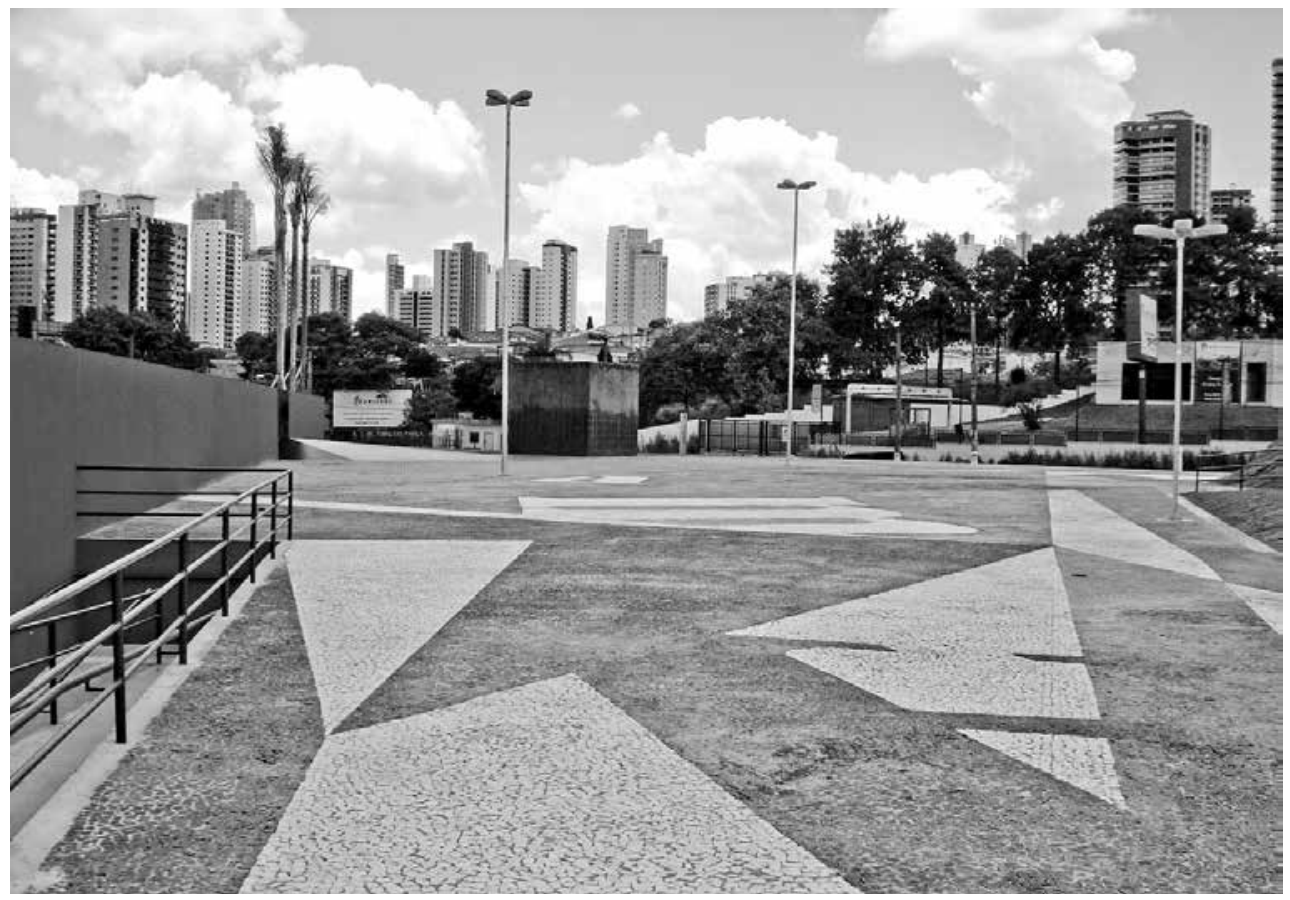

Figura 3: Praça Anna Santos Figueiredo

Crédito: Foto de Leonardo Loyolla, 2005 


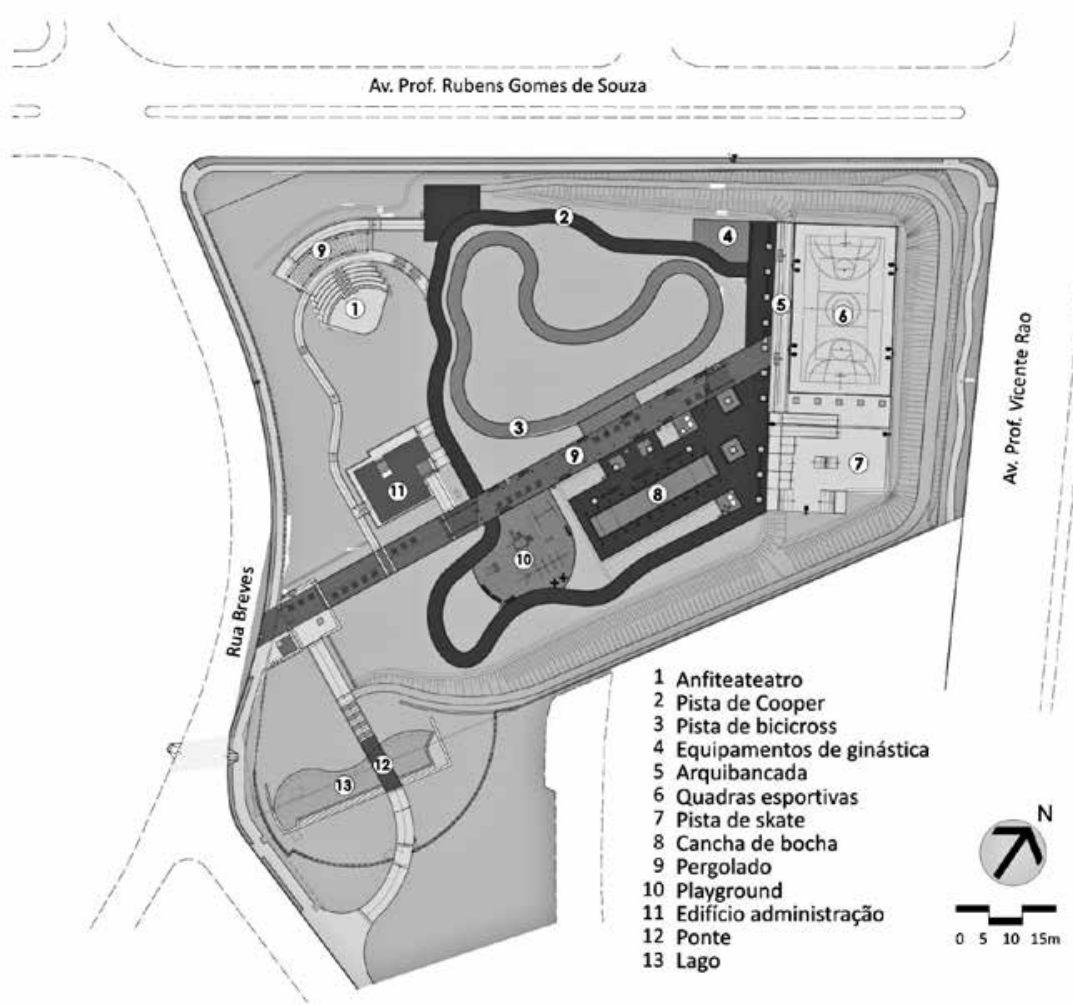

Figura 4: Parque do Cordeiro - Planta

Crédito: Foto de Leonardo Loyolla, 2007

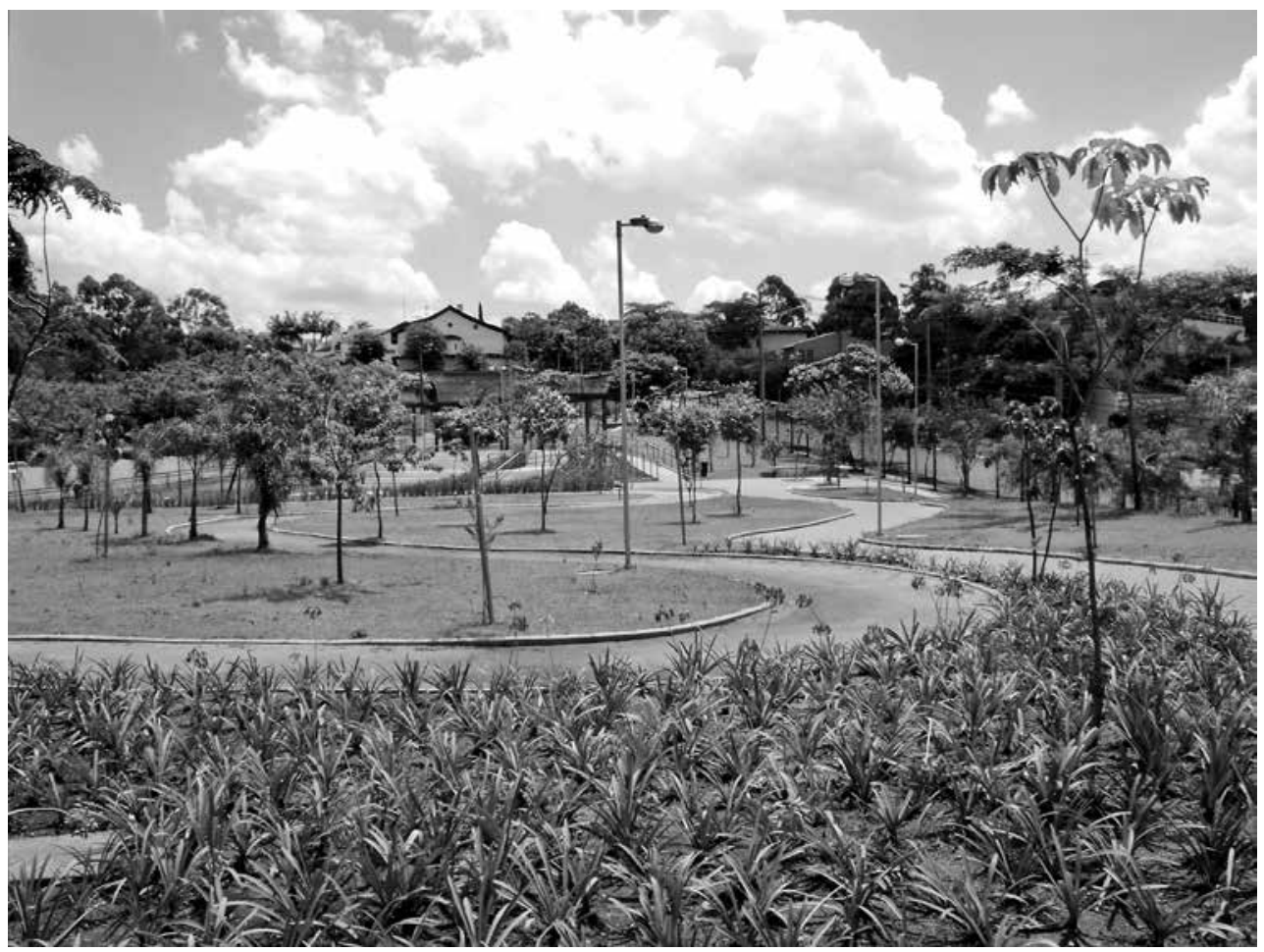

Figura 5: Parque do Cordeiro - Vista das pistas de cooper e bicycross

Crédito: Foto de Leonardo Loyolla, 2008 


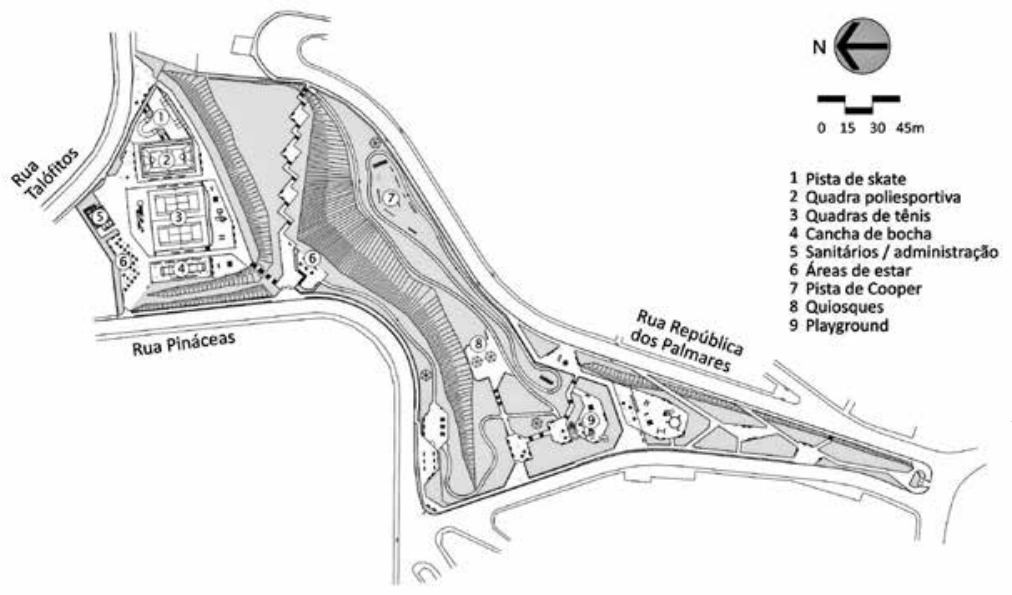

Figura 6: Parque Jacintho Alberto - Planta

Crédito: Foto de Leonardo Loyollla, 2008

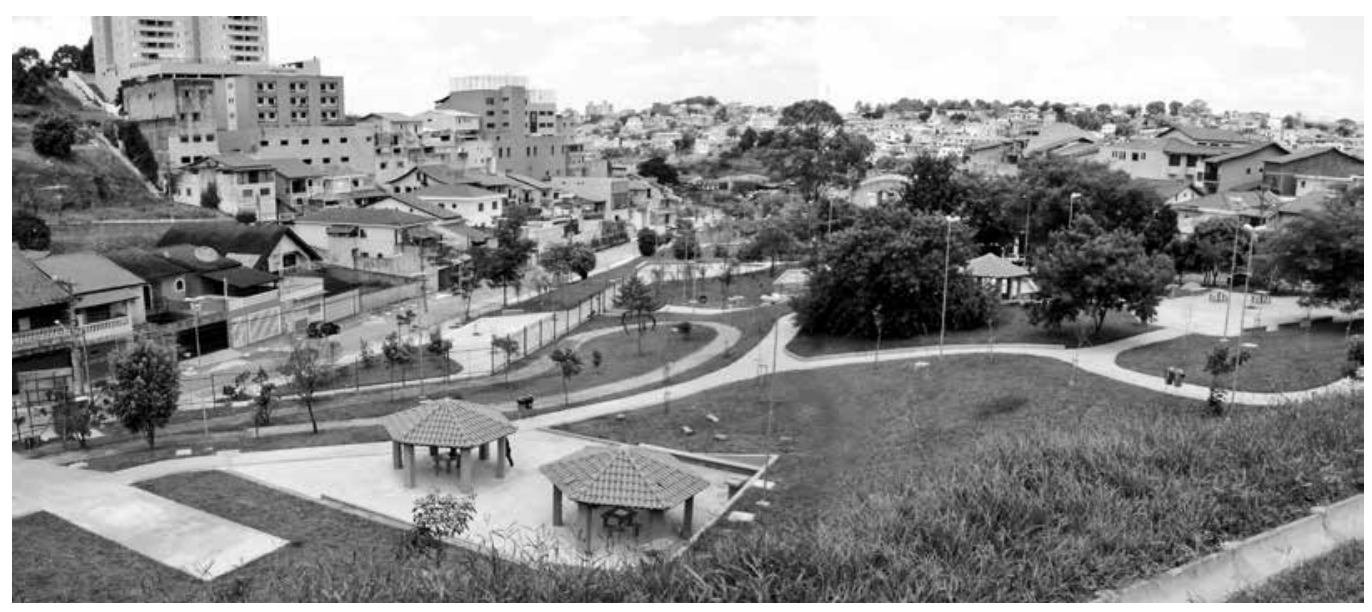

Figura 7: Parque Jacintho Alberto

Crédito: Foto de Leonardo Loyolla, 2008

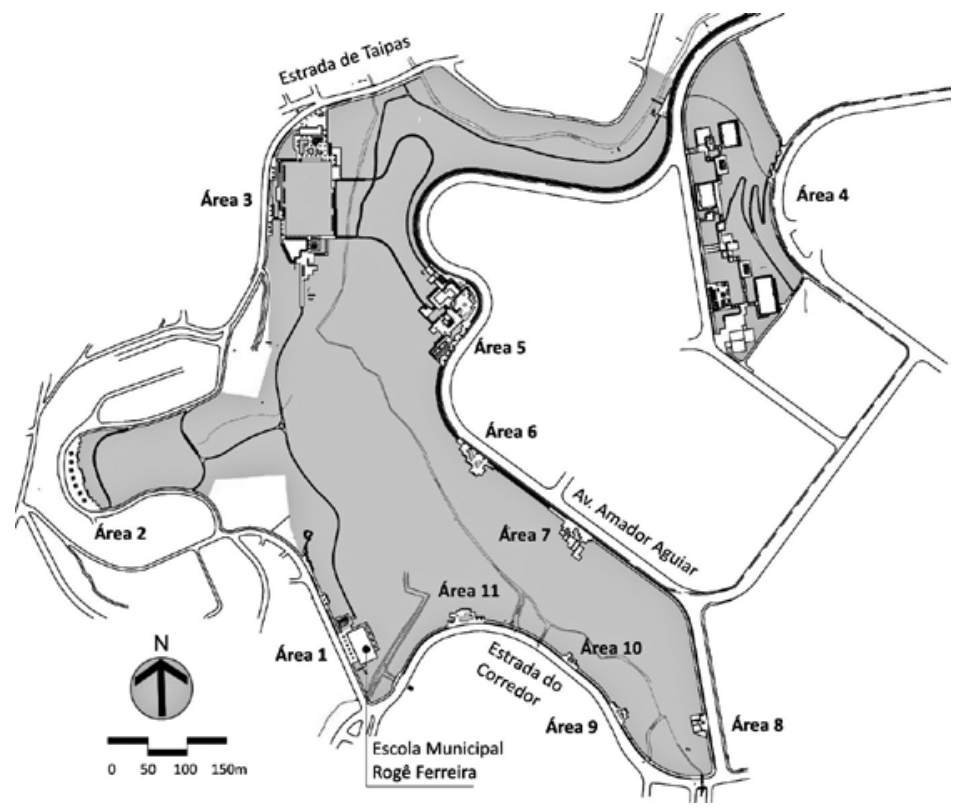

Figura 8: Parque Pinheirinho D'água - Planta

Crédito: Foto de Leonardo Loyolla, 2008 


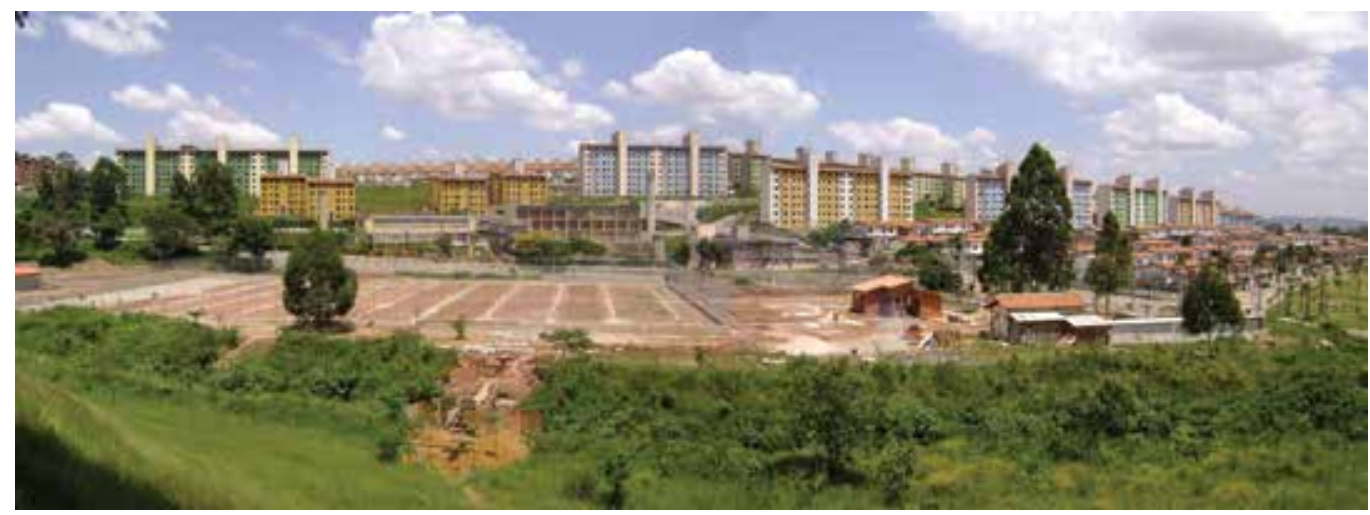

Figura 9: Parque Pinheirinho D'água - Vista geral da área 3, em fase de execução em 2008 Crédito: Foto de Leonardo Loyolla, 2008

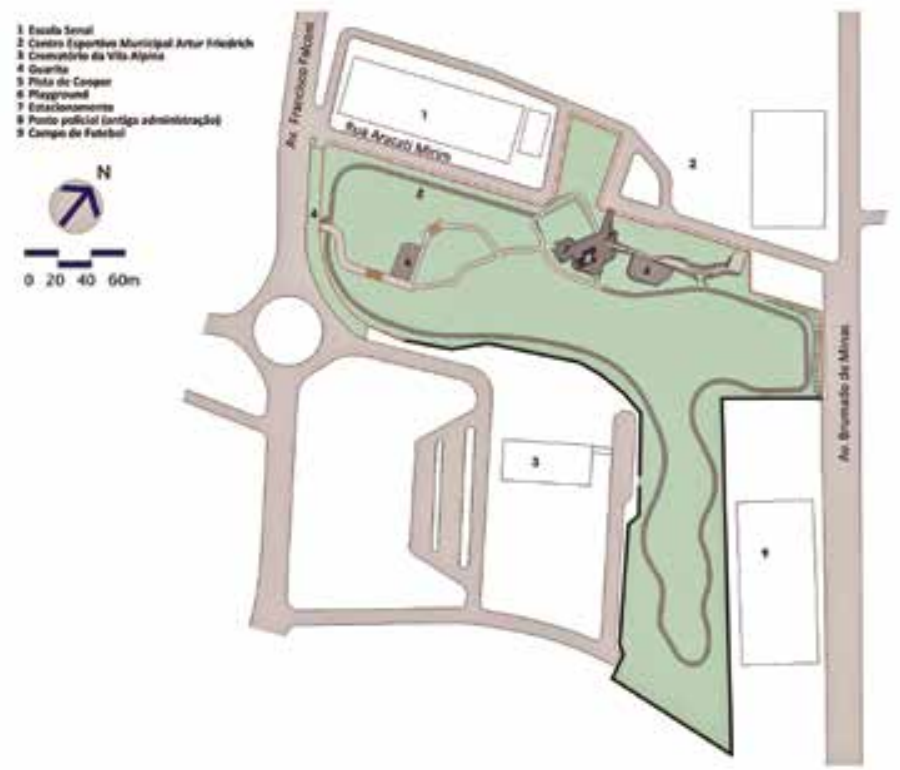

Figura 10: Parque da Vila Prudente - Planta

Crédito: Foto de Leonardo Loyolla, 2006

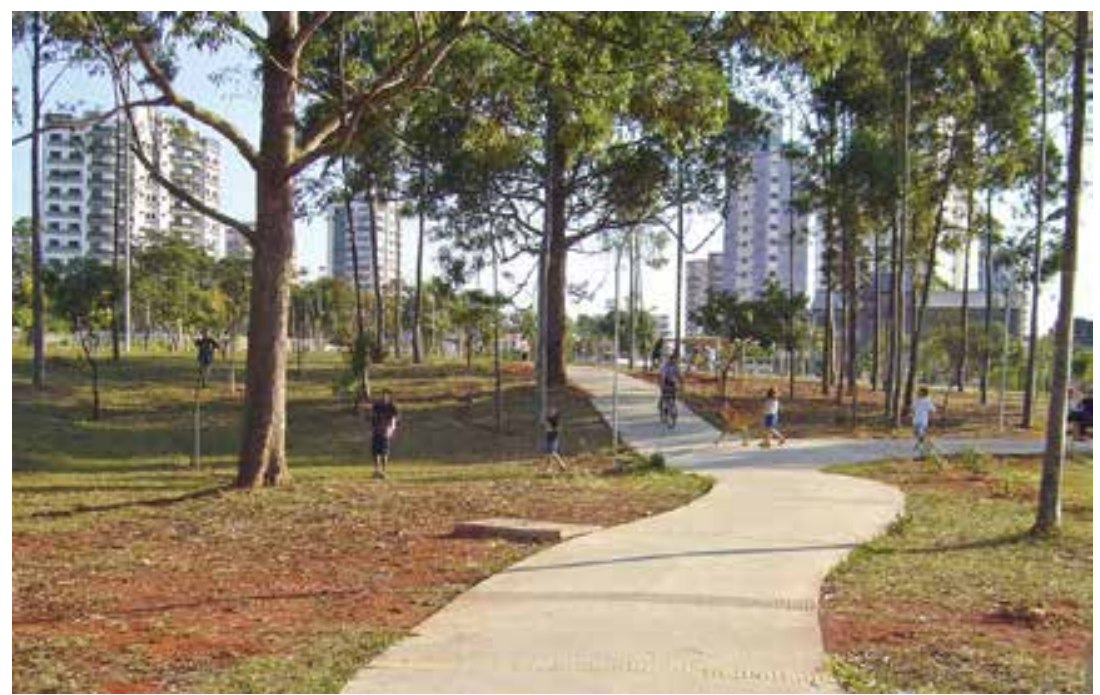

Figura 11: Parque da Vila Prudente Crédito: Foto de Leonardo Loyolla, 2005 
Considerando-se que as maiores demandas por espaços livres públicos do município encontram-se em suas áreas periféricas, esperava-se que as ações da prefeitura se concentrassem nesses lugares. $\bigcirc$ critério para implantação das áreas, no entanto, não correspondeu necessariamente às demandas da cidade. Algumas vezes esteve relacionado a interesses políticos.

Analisando-se o tipo de empreendimento que originou as compensações ambientais para custeio de espaços livres públicos paulistanos (Tabela 3), observa-se um predomínio dos usos residenciais e comerciais (73\% do total). Com relação ao tipo de empreendedor, observa-se que a maioria das compensações é gerada pela iniciativa privada (77\% dos casos).

A obtenção fragmentada de recursos para execução foi outra característica comum a todos os projetos aqui analisados. Provavelmente por esse motivo, obras de menor porte - como as praças Nandina Haddad Ambuba e Anna dos Santos Figueiredo foram finalizadas antes dos parques. Os demais projetos (concluídos até 2008) foram parcialmente executados e permaneceram desse modo por vários anos. Todos eles possuem maior porte, com mais de $30.000 \mathrm{~m}^{2}$.

Tabela 3: Tipologias geradoras de compensações ambientais alternativas ao plantio arbóreo no município de São Paulo entre os anos de 2005 e 2007

\begin{tabular}{l|c|c|c|c|c}
\hline Tipologia & $\mathbf{2 0 0 5}$ & $\mathbf{2 0 0 6}$ & $\mathbf{2 0 0 7}$ & Total & $\%$ \\
\hline Torre residencial & 8.602 & 19.505 & 6.368 & 34.475 & 50,8 \\
\hline Comercial & 10.552 & 4.181 & 264 & 14.997 & 22,1 \\
\hline Infra-estrutura & - & 10.379 & 1.531 & 11.910 & 17,5 \\
\hline Transporte & - & 2.477 & - & 2.477 & 3,6 \\
\hline Residência unifamiliar & 141 & 610 & 1.588 & 2.339 & 3,4 \\
\hline Obras diversas (público) & - & - & 930 & 930 & 1,4 \\
\hline Educacional (privado) & - & 615 & - & 615 & 0,9 \\
\hline Industrial & 128 & - & - & 128 & 0,2 \\
\hline Total & 19.423 & 37.767 & 10.681 & 67.871 & 100 \\
\hline
\end{tabular}

Crédito: Leonardo Loyolla

\section{PARQUES LINEARES}

Além das ações anteriormente citadas, as compensações ambientais passam, a partir de 2006, a viabilizar a construção de vários parques lineares no município de São Paulo. A ação é parte do Programa de Recuperação Ambiental de Cursos D'Água e Fundos de Vale, proposto pelo Plano Diretor Estratégico de 2002.

$\bigcirc$ plano incide sobre um dos universos mais degradados do município. Quando não estão completamente canalizados e fora do alcance da visão, a maioria dos cursos d'água existentes na cidade encontra-se poluída e ocupada por assentamentos irregulares a agravarem ainda mais esse problema, devido ao despejo irregular de esgoto e lixo. 
O programa foi deixado ao encargo da Coordenadoria de Planejamento Ambiental e Ações Descentralizadas da Secretaria de Verde e Meio Ambiente (Coplan). Ele vem ao encontro da valorização pelo poder público - a partir da década de 1990 - de medidas para melhoria da qualidade ambiental do município de São Paulo, tais como a despolvição e descanalização de cursos d'água, em oposição ao processo ocorrido nas décadas anteriores.

Por estar relacionada à questão dos recursos hídricos, a ação da SVMA recebeu auxílio da Companhia de Saneamento Básico do Estado de São Paulo (Sabesp) por meio do Programa Córrego Limpo'2, que passa a atuar na despolvição dos corpos d'água existentes em alguns dos parques previstos. A parceria entre a Sabesp e a prefeitura foi possível em grande parte devido ao fato de ambas as gestões pertencerem à mesma coligação partidária desse momento (PSDB no governo do estado e DEM na prefeitura), contribuindo para minimizar conflitos burocráticos. A ação permitiu que os benefícios em visibilidade fossem recolhidos pelas duas esferas.

Vários dos parques previstos para o programa utilizam Termos de Compromisso Ambiental (TCA) para viabilizar seu custeio. Muitas das compensações ambientais relacionadas a esses projetos são originadas por empreendimentos do próprio poder público, sobretudo obras viárias e de infra-estrutura urbana.

O programa é a primeira ação sistemática para implantação de espaços livres da gestão municipal Serra/Kassab. As últimas ações de porte semelhante a esta haviam ocorrido na gestão Marła Suplicy (2000-2004), pelo programa Centros de Bairro da Emurb e pela execução de uma primeira remessa de parques viabilizados por compensações ambientais no município (citada anteriormente).

A localização dos parques lineares previstos pelo programa prioriza as áreas periféricas, distribuindo-os de modo razoavelmente uniforme pelo município (Mapa 2, Tabela 4).

A implantação de parques lineares, além de contribuir para amenizar o déficit de espaços livres públicos no município, também permite auxiliar na recuperação e posterior preservação dos corpos d'água. Além disso, devido ao caráter linear, tais espaços livres atendem a trechos mais extensos da malha urbana em comparação às ações pontuais.

Embora constitua uma ação louvável do poder público, o programa enfrenta diversos problemas de organização que dificultam sua efetiva implantação. A quantidade de parques previstos, por exemplo, alterava-se a cada nova divulgação do poder público entre 2007 e 2008, variando de um total de 20 a 40.

A forma de custeio dos parques também sofreu quantidade semelhante de variações, estando ora vinculada a recursos próprios da SVMA, ora ao Fundo de Desenvolvimento Urbano (Fundurb) ou aos TCAs. Tais flutuações se devem, em grande parte, à fragmentação e suscetibilidade das compensações ambientais paulistanas em relação ao processo de aprovação dos empreendimentos. Essas incertezas dificultam a determinação da fonte de custeio das obras, mesmo que os TCAs sejam responsáveis pelas verbas para a maioria dos parques em qualquer uma das previsões feitas pela prefeitura. 
Mapa 2 - Parques Lineares

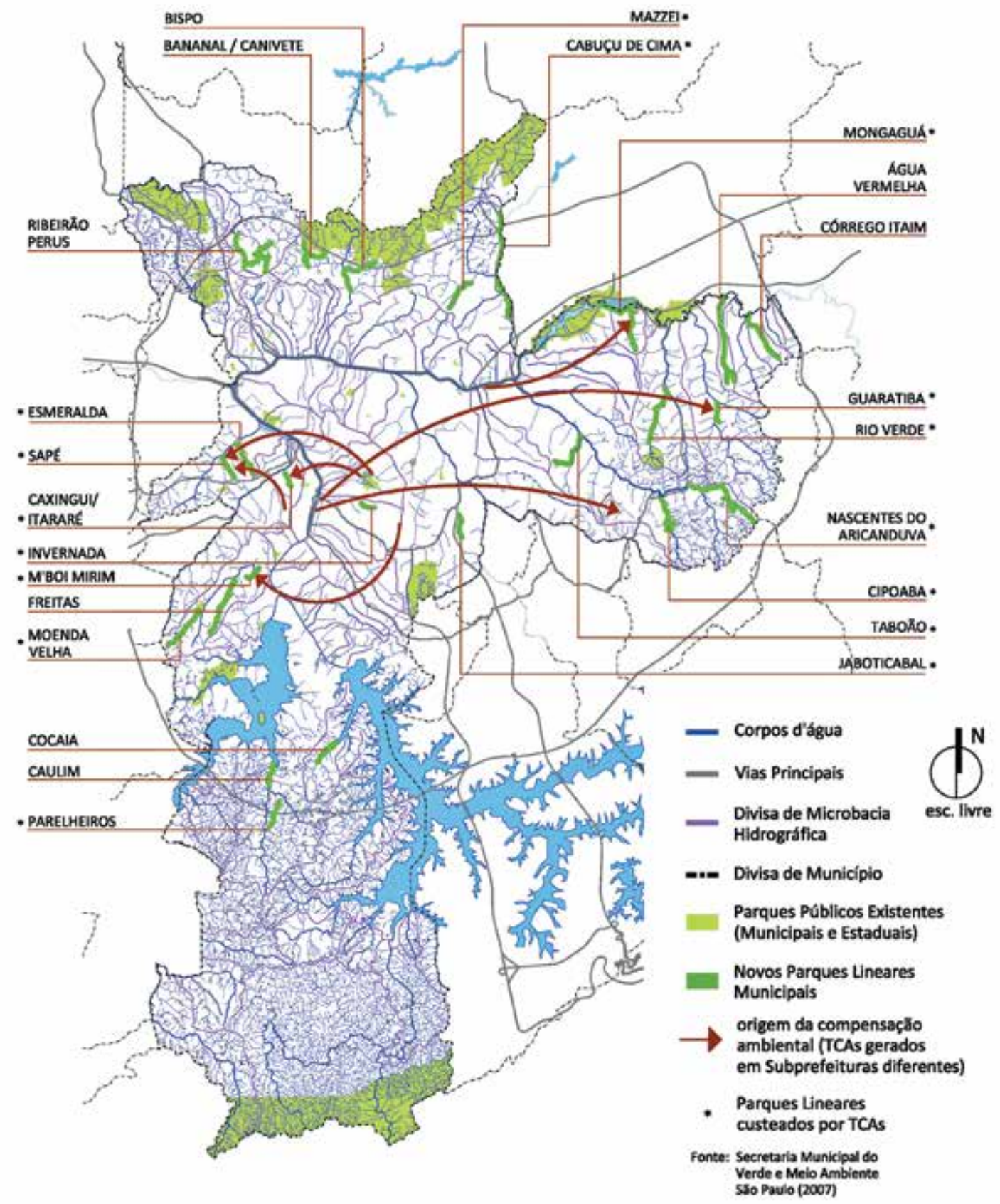

Fonte: Secretaria Municipal de Verde e Meio Ambiente, 2007 
Tabela 4: Parques lineares previstos para o município de São Paulo a partir do ano de 2007

\begin{tabular}{|c|c|c|c|c|c|}
\hline Nome & Empreendedor & Tipologia & A & $\begin{array}{c}\text { Subprefeitura } \\
\text { origem }\end{array}$ & $\begin{array}{c}\text { Subprefeituro } \\
\text { destino }\end{array}$ \\
\hline $\begin{array}{l}\text { Cabuçu de } \\
\text { Cima }\end{array}$ & privado & residencial & residencial & $\begin{array}{c}\text { Vila Maria / } \\
\text { Vila Guilherme }\end{array}$ & $\begin{array}{c}\text { Vila Maria / } \\
\text { Vila Guilherme }\end{array}$ \\
\hline \multirow{2}{*}{ Cipoaba } & público & viário & $\begin{array}{l}\text { complexo } \\
\text { viário }\end{array}$ & Santo Amaro & \multirow{2}{*}{ São Mateus } \\
\hline & privado & residencial & torre & Santo Amaro & \\
\hline Guaratiba & público & viário & avenida & Santo Amaro & $\begin{array}{l}\text { Cidade } \\
\text { Tiradentes }\end{array}$ \\
\hline Invernada & público & viário & avenida & Santo Amaro & Santo Amaro \\
\hline Itapaiúna & público & viário & avenida & Santo Amaro & Campo Limpo \\
\hline Jaboticabal & privado & residencial & torre & Santo Amaro & Ipiranga \\
\hline Lajeado & privado & residencial & loteamento & Butantã & Itaquera \\
\hline M'Boi Mirim & privado & residencial & $\begin{array}{c}\text { abertura } \\
\text { viário }\end{array}$ & Santo Amaro & M'Boi Mirim \\
\hline Moenda Velha & público & educacional & escola & Campo Limpo & Campo Limpo \\
\hline Mongaguá & privado & educacional & universidade & Mooca & São Miguel \\
\hline Parelheiros & público & viário & $\begin{array}{l}\text { corredor de } \\
\text { ônibus }\end{array}$ & Parelheiros & Parelheiros \\
\hline Rio Verde & privado & comercial & shopping & Itaquera & Itaquera \\
\hline \multirow{3}{*}{ Sapé } & privado & residencial & $\begin{array}{c}\text { conjunto } \\
\text { habitacional }\end{array}$ & Butantã & \multirow{3}{*}{ Butantã } \\
\hline & \multirow{2}{*}{ privado } & comercial & shopping & Butantã & \\
\hline & & espaço livre & parque & Vila Mariana & \\
\hline Taboão & público & Infra-estrutura & $\begin{array}{c}\text { canalização } \\
\text { de córrego }\end{array}$ & Itaquera & Itaquera \\
\hline Butantã & privado & serviços & hotel & Pinheiros & Butantã \\
\hline Mazzei & público & transportes & metrô & $\begin{array}{l}\text { Santana/ } \\
\text { Tucuruvi }\end{array}$ & $\begin{array}{l}\text { Santana/ } \\
\text { Tucuruvi }\end{array}$ \\
\hline Esmeralda & público & Infra-estrutura & & Santo Amaro & Butantã \\
\hline
\end{tabular}

Crédito: Leonardo Loyolla 
Outro entrave enfrentado pelo programa é a remoção das favelas existentes nas áreas previstas para esses parques. As dificuldades se relacionam não só à obtenção de recursos para o devido assentamento das famílias retiradas, como também pelas dificuldades de comunicação entre as diversas repartições públicas necessárias a esse tipo de operação.

Devido aos problemas citados, apenas três dos parques previstos pelo programa encontravam-se em obras no início do ano de 2008: Sapé (Subprefeitura do Butantã - Figuras 12 e 13), Invernada (Subprefeitura de Santo Amaro) e Parelheiros, sendo este último o único completamente executado ${ }^{13}$. Todos os três foram custeados por compensações ambientais.

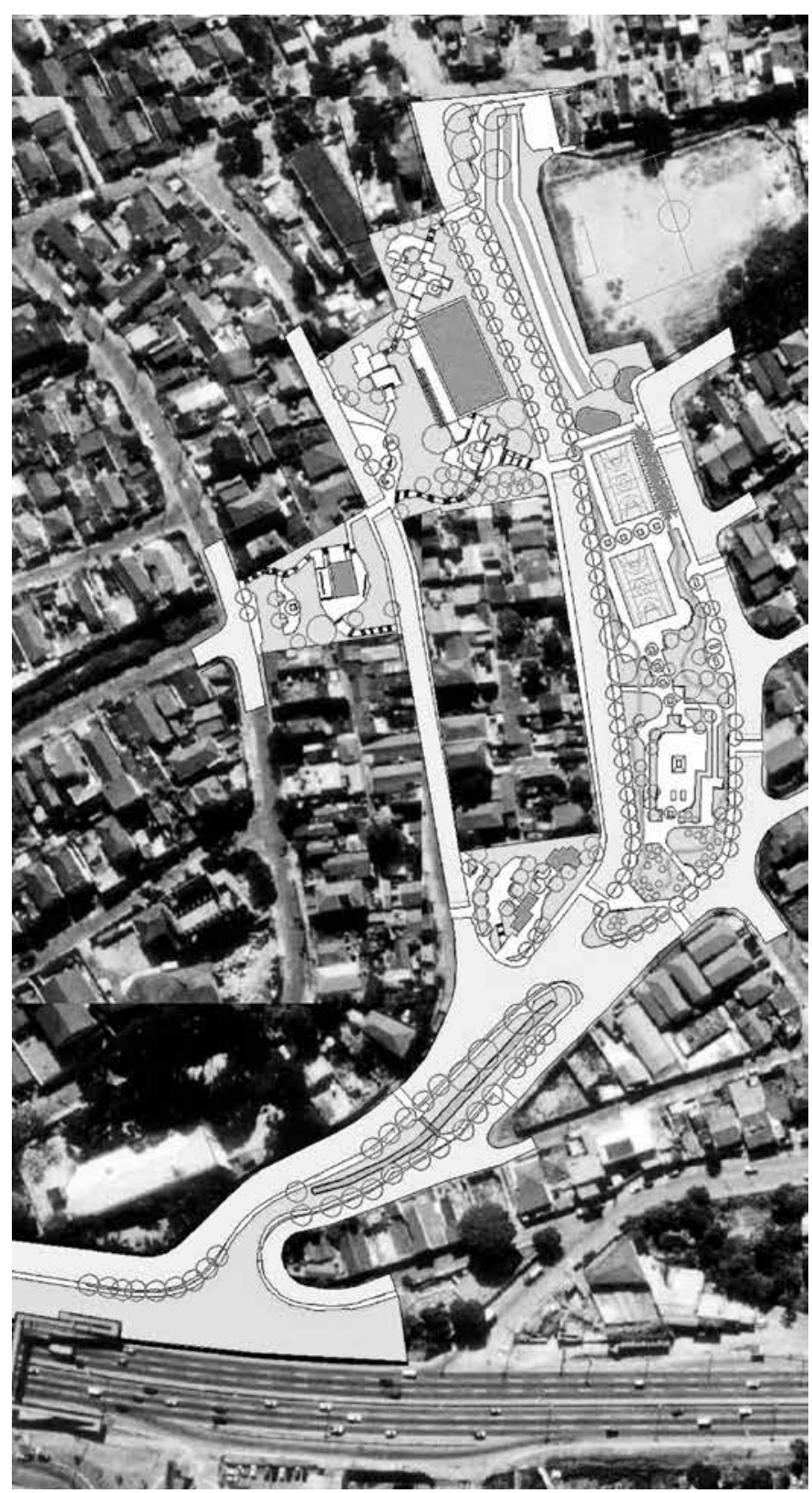

Figura 12: Parque do Sapé - Planta Fonte: Equipe da subprefeitura do Butantã, 2006 


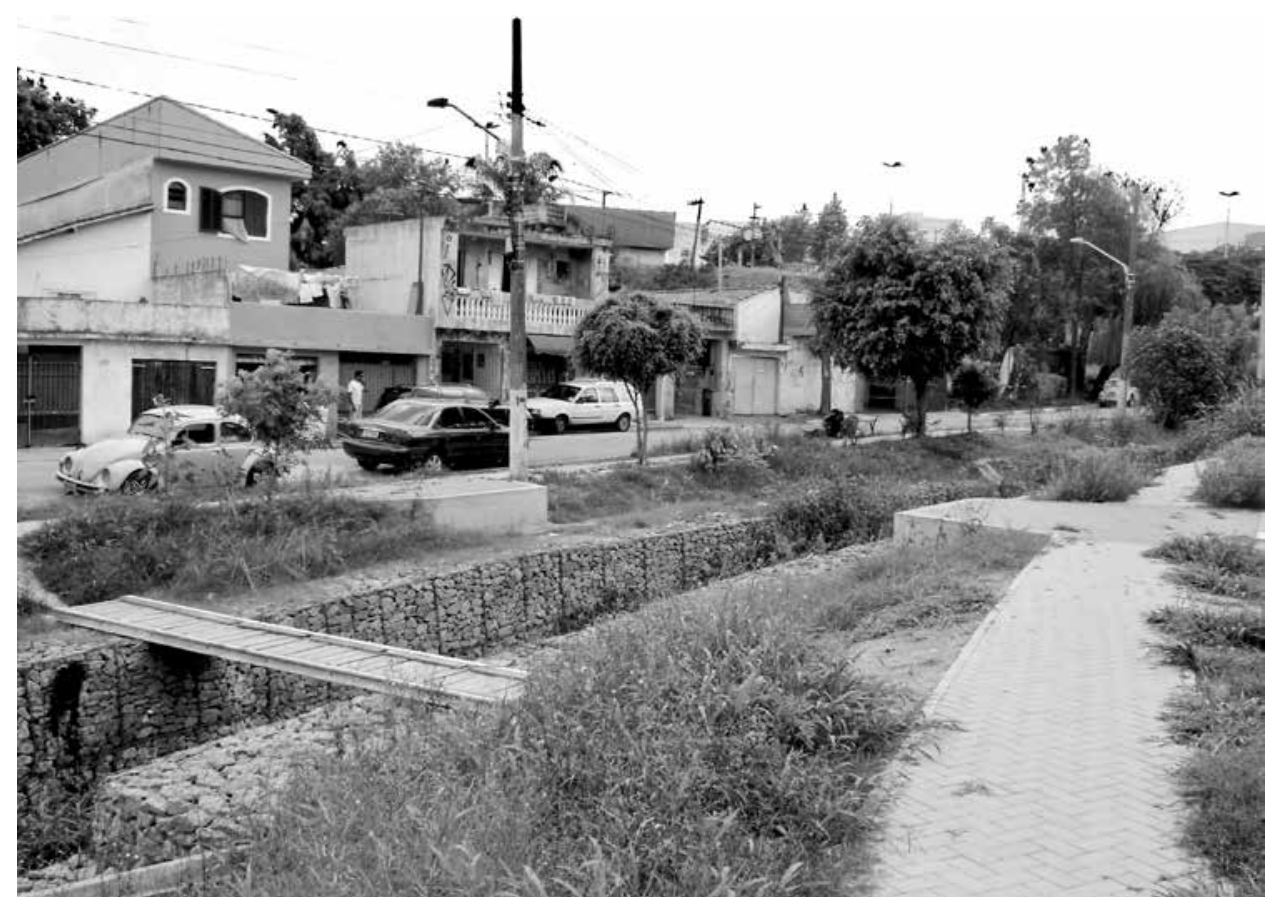

Figura 13: Parque do Sapé

Crédito: Foto de Leonardo Loyolla, 2008

\section{UM BALANÇO GERAL}

Embora alguns técnicos do poder público não acreditem no potencial das compensações ambientais como fonte de custeio de novos espaços livres, uma parte considerável dos parques públicos implantados no município entre 1998 e 2008 foram custeados por TCAs.

Ao longo de seu desenvolvimento no município de São Paulo, as compensações ambientais se mostraram suscetíveis às mudanças de postura de cada gestão. A confrontação do texto da lei com a realidade da época na qual esse foi alterado evidencia mudanças ocorridas em função de interesses políticos. Situações ocorridas em diferentes gestões exemplificam essa subordinação da legislação aos interesses políticos de cada época.

A necessidade de finalizar as obras de parques públicos prioritários nas gestões Marta Suplicy e Serra/Kassab foi um dos fatores que motivaram o aumento da possibilidade de compensação por obras e serviços ${ }^{14}$. Esses aumentos podem ser observados na Tabela 5.

Outro caso emblemático foi a redução da quantidade de árvores necessárias para a compensação pela retirada de eucaliptos e pinus para um patamar de 1:1 (ou seja: a cada árvore retirada, apenas uma é plantada no lugar), levada a efeito na Gestão Serra/Kassab ${ }^{15}$. As sucessivas alterações nas proporções compensatórias podem ser vistas na Tabela 6. Tal ação foi ao encontro das pressões do mercado imobiliário, visto ser esse o tipo de vegetação arbórea mais freqüentemente encontrado nos terrenos ainda disponíveis para novos empreendimentos na cidade de São Paulo. 


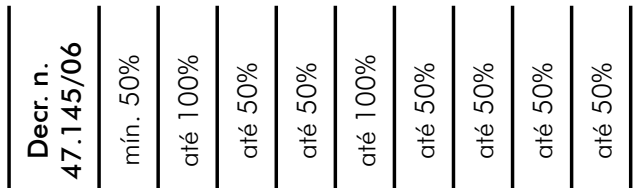 \\ ப ㅇํㄹ

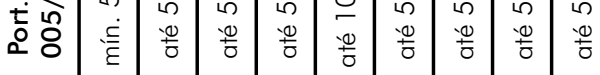
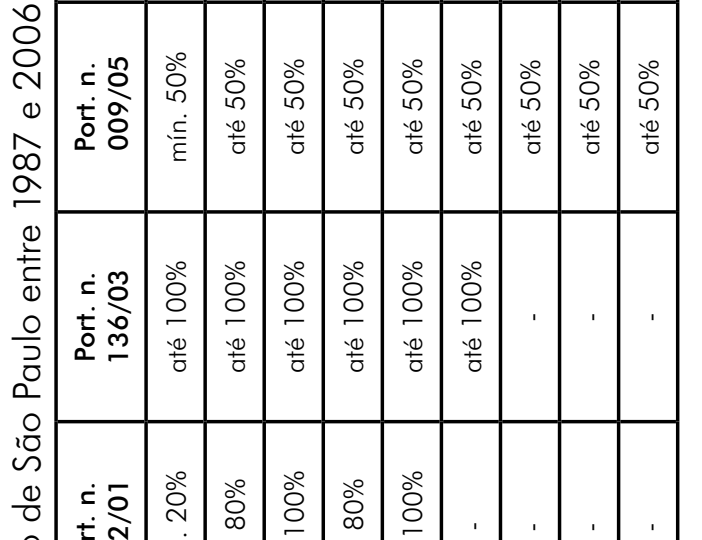

资

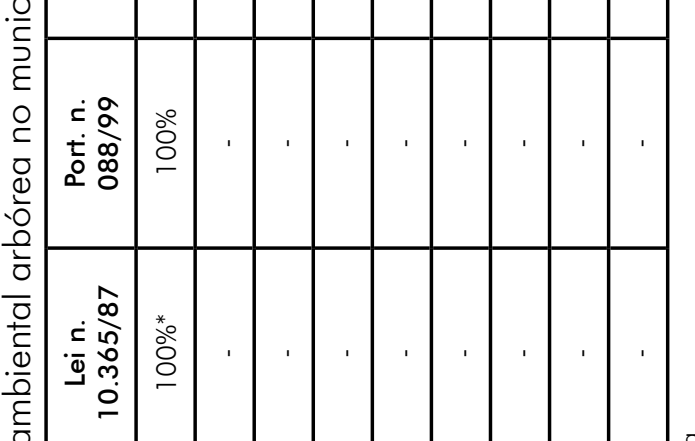

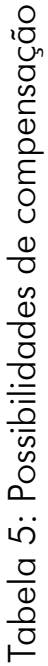
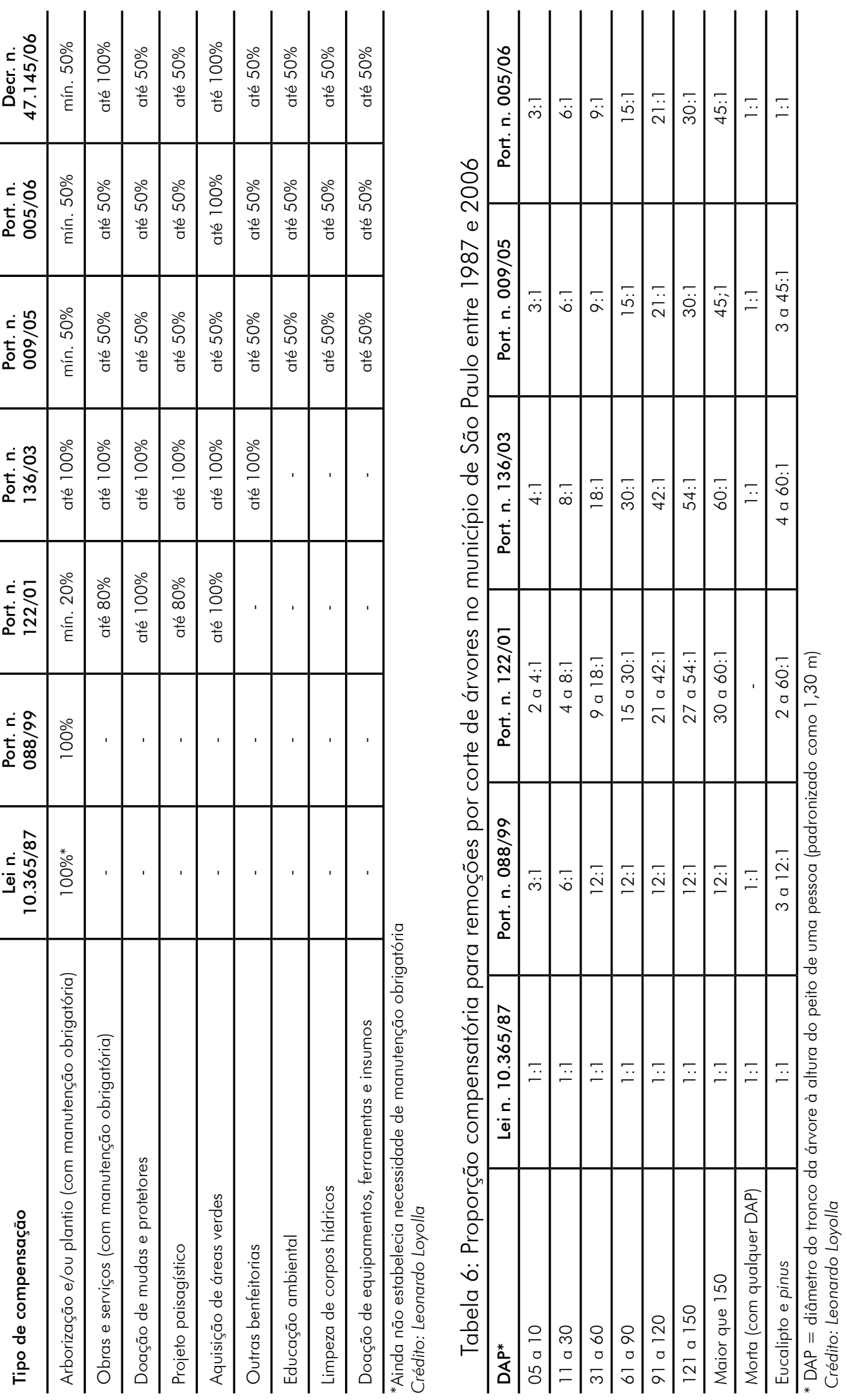
Por outro lado, as compensações ambientais podem contribuir para atenuar as desigualdades na distribuição de espaços livres na cidade, direcionando recursos provenientes das áreas de maior poder aquisitivo para locais mais carentes. Mas sua utilização inadequada pode surtir o efeito oposto, dependendo do local onde é realizada. Por princípio, os processos compensatórios sempre buscam gerar quantidades de mudas maiores do que a quantia de árvores retirada por um empreendimento. Caso esse excedente seja plantado no entorno que já possui arborização satisfatória, satura-se um local com plantio enquanto as demais regiões da cidade continuam perdendo sistematicamente sua cobertura arbórea.

Existem ainda os casos de compensação nos quais simplesmente não há espaço físico disponível para a locação de todas as árvores solicitadas pela prefeitura ao empreendedor. Situações como essa levam ao contra-senso do poder público ter disponível uma quantia considerável de mudas para plantio sem saber onde plantálas. Como resultado, usualmente adota-se dois tipos de solução para cumprir as obrigações previstas pela lei. Uma delas consiste no plantio das mudas nos espaços livres públicos que ainda restaram na circunscrição da subprefeitura. Geralmente são locais de pouca ou nenhuma relevância, como áreas residuais do sistema viário e rotatórias. Além de não contribuírem para a melhoria do sistema de espaços livres da cidade, a chance de sobrevivência das mudas nesses locais é bastante reduzida, dado o usual estado de abandono que se encontram e a maior suscetibilidade às ações de vandalismo.

Em outros casos, a subprefeitura escolhe os locais com maior visibilidade, mesmo que estes já possuam arborização significativa. Isso leva a uma saturação de plantio a qual contrasta com as grandes carências desse quesito em outras regiões da cidade.

Essas duas medidas resultam do entendimento da compensação ambiental por critérios numéricos e burocráticos. Enquanto isso, uma considerável porção da cidade permanece com carência de arborização.

O problema para identificação das áreas a compensar também se deve à inexistência de um plano de espaços livres e arborização para o município e a uma gestão deficiente do processo. Essa opinião é compartilhada não só pelos profissionais do próprio poder público, como também pelos envolvidos nas diversas etapas das compensações ambientais no município.

No entanto, ao mesmo tempo em que apresentam diversos aspectos a serem aperfeiçoados, as compensações ambientais resultaram em ações concretas que, em maior ou menor grau, contribuíram para melhorias no sistema de espaços livres públicos do município de São Paulo.

mecanismo auxiliou a captar recursos para um processo de viabilização de espaços livres que há muito não ocorria na cidade ${ }^{16}$. Em sete anos - de 2001 a 2008 - as compensações ambientais viabilizaram a construção de seis parques (do Cordeiro, Jacintho Alberto, Vila Prudente, Pinheirinho D'Água, Linear do Sapé e de Parelheiros) e duas praças (Nandina Haddad Ambuba e Anna dos Santos Figueiredo), abertos ao público total ou parcialmente. Além disso, foram responsáveis por cerca de 1.000 casos 
que contribuíram de modos diversos para o enriquecimento da arborização urbana no município de São Paulo ${ }^{17}$.

Excetuando o Parque da Vila Prudente (projetado pela equipe DEPAVE), a responsabilidade pelo projeto de todos esses novos parques e praças foi entregue à iniciativa privada. Tal fato estabelece uma nova dinâmica no processo de criação de espaços livres públicos municipais, caracterizada pela maior influência da iniciativa privada. Se, por um lado, esse processo acentuou as dificuldades de produção devido aos conflitos mútuos para aceitação de diferentes modos de pensar do poder público e privado, por outro lado criou a possibilidade de aumento do padrão de qualidade dos projetos e alívio da sobrecarga da municipalidade.

A quantidade de parques custeados por compensações ainda é irrisória perto das carências da cidade, mas representa melhoras, se comparada à estagnação existente em períodos anteriores.

As compensações ambientais também contribuíram para a melhor distribuição de espaços livres na cidade de São Paulo. Embora as compensações externas ao local do dano ambiental constituam exceção ao processo compensatório global, deve ser considerado seu potencial de atuação no sentido de amenizar a distribuição desigual de áreas de lazer no município. As compensações podem permitir que a área da cidade com melhor distribuição de espaços livres - no caso do município de São Paulo, a região sudoeste - desempenhe um papel importante no direcionamento de recursos para as outras regiões.

Três motivos atuam de forma conjunta para explicar a relevância dessa região no contexto da geração de compensações.

$\bigcirc$ primeiro é o fato de essa região abrigar bairros com urbanização predominantemente planejada, que possuem maior quantidade de arborização, tais como os Jardins, o Morumbi e o Brooklin. A existência de arborização urbana mais densa eleva o número de compensações ambientais necessárias, seja pela implantação de novos empreendimentos, seja pela reposição dos exemplares existentes.

O segundo é a capacidade de polarização da região para novos empreendimentos do setor imobiliário, notadamente aqueles de padrão de renda mais elevado, que possuem efetivas capacidades de custeio de compensações. Como foi visto anteriormente, os empreendimentos residenciais e comerciais são responsáveis pela maioria das compensações ambientais realizadas no município até 2008. Além disso, tradicionalmente, a região também recebe maior quantidade de investimentos do poder público em comparação a outros locais da cidade.

Um terceiro motivo se relaciona à existência de maior fiscalização na região sudoeste, quando comparada a outros locais do município. Tal fato se deve à maior visibilidade do local perante a opinião pública, pois nele se encontra uma parte considerável da população de maior poder aquisitivo do município.

Somando-se esses elementos, temos a área da cidade onde não só as ações do poder público são mais efetivas, possibilitando a geração de mais compensações, como também os recursos para custeá-las são mais elevados. 
Outro aspecto positivo das compensações ambientais na cidade de São Paulo foi o constante aperfeiçoamento da legislação ao longo de dez anos de sua existência. Da simples reposição arbórea (plantio de uma árvore para cada uma retirada) prevista pela Lei Municipal n. 10.365/1987, chegou-se a sofisticadas (dir-se-ia até mesmo complicadas) fórmulas matemáticas, que buscam atenuar danos ambientais por meio de variados critérios de valoração ecológica.

Os aspectos técnicos relativos ao cálculo das compensações foram dos que mais evoluíram. Isso talvez reflita o papel de destaque que a área da engenharia agronômica tem desempenhado na evolução do mecanismo. As portarias emitidas pelo DEPAVE, a partir de 2005, levam em consideração não só o porte da árvore retirada como também sua localização na cidade e espécie, introduzindo o conceito de valoração ecológica. E a quantia compensatória aumentou consideravelmente, apesar de alguns retrocessos, como o caso do estabelecimento da proporção 1:1 para eucaliptos e pinus, anteriormente citado. Vale citar, no entanto, que os esforços no aperfeiçoamento técnico do texto da legislação não se refletiram, necessariamente, na melhora da estrutura de aplicação, o que pode comprometer todo o trabalho.

Ao mesmo tempo, a legislação aumentou gradativamente em importância, consolidando-se como pré-requisito para aprovação de novos empreendimentos. Bem ou mal quista pelo setor imobiliário, a compensação se tornou uma variável que eleva a importância da percepção dos aspectos ambientais no projeto do edifício. Para alguns profissionais do poder público, a relevância das compensações no projeto deveria ir além das modificações pontuais, visando atender às exigências legais. Deveria condicionar o modo de projetar às variáveis ambientais. Mas não foi estabelecido, pelo poder público, referências de projetos arquitetônicos ambientalmente adequados.

Além disso, a variável que ainda mais pesa no momento de conceber novos empreendimentos é a econômica. Por esse motivo, diversos representantes do poder público consideram que o custo das compensações deveria ser alto o suficiente para inibir projetos ambientalmente inadequados. Isso não tem ocorrido. Pelo contrário: medidas como a mudança da proporção compensatória de eucaliptos e pinus para 1:1 reduziram o custo de uma parte considerável das compensações no município. Isso evidencia que a percepção das variáveis ambientais ainda não é quesito suficiente para alterações substanciais na concepção dos projetos. Porém as alterações promovidas pelas compensações ambientais no município representam algum avanço.

\section{Notas}

(1) A participação da Secretaria de Verde e Meio Ambiente no orçamento municipal, aprovado entre 2000 e 2004 , não superou o reduzido patamar de $0,73 \%$ do total (esse valor ocorreu em 2003). Nesse mesmo ano, os gastos com pavimentação de vias públicas correspondiam a 1,02\% do orçamento total do município. GEO cidade de São Paulo: Panorama do meio ambiente urbano. Brasília: PNUMA, 2004, p. 27 e 147.

(2) Em 2002, de um total de 370 praças com mais de $6.000 \mathrm{~m}^{2}$ na cidade de São Paulo, apenas "[...] os distritos Sé, Alto de Pinheiros, Vila Formosa e Morumbi dispõem, cada um deles, do maior número [...], entre 15 e 24. Grande parte dos distritos, num total de 46, possui apenas, no máximo, 5 praças". GEO cidade de São Paulo: Panorama do meio ambiente urbano. Brasília: PNUMA, 2004, p. 109. 
(3) A medida mais significativa nesse sentido, até 2008, foi o Plano de Áreas Verdes para a Cidade de São Paulo, de 1967, coordenado pelas arquitetas paisagistas Miranda Martinelli Magnolli e Rosa Grena Kliass.

(4) Ação realizada pela Empresa Municipal de Urbanização (Emurb) entre 2001 e 2004, responsável pela implantação de 57 projetos paisagísticos, distribuídos em cada uma das subprefeituras do município de São Paulo. Ver SAKATA, Francine Gramacho. O projeto paisagístico como instrumento de requalificação urbana. Dissertação de mestrado. São Paulo: FAUUSP, 2004, p. 103-225.

(5) O Plano Diretor Estratégico da Cidade de São Paulo (Lei Municipal n. 13.430/2002), em seu art. 107, menciona a busca por "ampliar os espaços de lazer ativo e contemplativo, criando progressivamente parques lineares ao longo dos cursos d'água e fundos de vales não urbanizados".

(6) Secretaria Municipal de Verde e Meio Ambiente, 2008.

(7) Por meio da Portaria n. 088/SMMA.G., de 04 de setembro de 1999.

(8) Possibilidades introduzidas a partir da Portaria n. 122/SMMA.G., de 11 de outubro de 2001.

(9) MACEDO, Silvio Soares. Quadro do paisagismo no Brasil. São Paulo: FAUUSP, 2000, p. 13.

(10) Todos os dados citados nesse subtópico referem-se a informações obtidas na Secretaria Municipal de Verde e Meio Ambiente em 2008.

(11) Essa região, no entanto, receberia, nesse período, o projeto do Parque do Gato, de autoria do arquitetopaisagista Raul Pereira.

(12) Iniciado em março de 2007, o programa da Sabesp teve como escopo inicial a despolvição de 42 córregos da cidade de São Paulo. Em fevereiro de 2008, segundo informações divulgadas pelo website do programa (www. corrego limpo.com.br), sete cursos d'água haviam sido despoluídos.

(13) Inaugurado em novembro de 2007.

(14) Por meio da Portaria DEPAVE n. 136/2003 (gestão Marta Suplicy) e pelo Decreto Municipal n. 47.145 (gestão Serra/Kassab).

(15) Por meio da Portaria DEPAVE n. 005/2006.

(16) A última ação de maior envergadura relacionada à produção de espaços livres públicos no município de São Paulo havia sido empreendida pelo Departamento de Parques e Áreas Verdes de São Paulo (DEPAVE) entre 1974 e 1984, quando foram executados cerca de $625 \mathrm{mil} \mathrm{m}^{2}$ de praças e 11 parques públicos, que totalizaram quase 12.000.000 $\mathrm{m}^{2}$ de área. Além das ações empreendidas pelo DEPAVE nesse período, também foram executadas praças projetadas pela Companhia do Metropolitano de São Paulo e pela Empresa Municipal de Urbanização (Emurb). Ver STESCHENKO, Wolfgang Sergio. Contribuição ao estudo e ao processo de produção da praça pública paulistana - O Departamento de Parques e Áreas Verdes de São Paulo de 1967 a 1979. Dissertação de Mestrado. São Paulo: FAUUSP, 2001; BARTALINI, Vladimir. Parques públicos municipais de São Paulo. Tese de doutorado. São Paulo: FAUUSP, 1999.

(17) SVMA, 2008.

\section{Bibliografia}

COELHO, Leonardo Loyolla. Compensação ambiental: Uma alternativa para a viabilização de espaços livres públicos para lazer e convívio na cidade de São Paulo. 2008. Dissertação (Mestrado) - Faculdade de Arquitetura e Urbanismo, Universidade de São Paulo, São Paulo, 2008.

MACEDO, Silvio Soares. Quadro do paisagismo no Brasil. São Paulo: FAUUSP, 2000.

SAKATA, Francine Gramacho. O projeto paisagístico como instrumento de requalificação urbana. 2004. Dissertação (Mestrado) - Faculdade de Arquitetura e Urbanismo, Universidade de São Paulo, São Paulo, 2004.

SÃO PAULO (cidade). Plano Diretor Estratégico. Lei n. 13.430 de 13 de setembro de 2002. São Paulo: Secetaria Municipal de Planejamento Urbano, 2002.

SÃO PAULO (cidade). Secretaria de Verde e Meio Ambiente. IPT. GEO cidade de São Paulo: Panorama do meio ambiente urbano. Brasília: PNUMA, 2004.

SILVA FILHO, Carlos Alberto da. Proteção e fomento da vegetação no município de São Paulo: Possibilidades, alcance e conflitos. 2005. Tese (Doutorado) - Faculdade de Arquitetura e Urbanismo, Universidade de São Paulo, São Paulo, 2005. 